\title{
ANALISIS KESUBURAN PERAIRAN BERDASARKAN KELIMPAHAN FITOPLANKTON, NITRAT DAN FOSFAT DI PERAIRAN SUNGAI BENGAWAN SOLO KOTA SURAKARTA
}

\author{
The Analysis Of Fertilizer Supply Based On Phytoplankton, Nitrate and Phosphate \\ in the River Bengawan Solo City Of Surakarta
}

\section{Arif Darmawan, Bambang Sulardiono*), Haeruddin}

Program Studi Manajemen Sumberdaya Perairan, Departemen Sumberdaya Akuatik Fakultas Perikanan dan Ilmu Kelautan, Universitas Diponegoro Jl. Prof. Soedarto, SH, Tembalang, Semarang, Jawa Tengah, Indonesia Email: darmawanarif9412@gmail.com

\begin{abstract}
ABSTRAK
Kegiatan rumah tangga dan industri memanfaatkan sungai Bengawan Solo untuk membuang limbahnya. Hal tersebut dapat menurunkan kualitas perairan di Sungai Bengawan Solo. Perubahan kualitas perairan akan berpengaruh langsung terhadap organisme yang hidup di sungai tersebut. Keberadaan fitoplankton di suatu perairan dapat memberikan informasi mengenai keadaan perairan. Tujuan dari penelitian ini adalah untuk mengetahui struktur komunitas fitoplankton, mengetahui konsentrasi nutrien (nitrat dan fosfat) serta mengetahui hubungan kelimpahan fitoplankton dengan konsentrasi nutrien. Metode yang digunakan dalam penelitian ini adalah metode survei. Hasil penelitian ini menunjukkan bahwa komposisi jenis fitoplankton yang ditemukan selama pengamatan didominasi oleh kelas Bacillariophyceae. Genus Rhizosolenia sp., Nitzschia sp. dan Navicula sp. Kelimpahan fitoplankton pada stasiun I sebesar 2544 ind/L. Stasiun II sebesar 1975 ind/L. Stasiun III sebesar 2735 ind/L. Stasiun IV sebesar 1785 ind/L dan stasiun V sebesar 2418 ind/L. Indeks keanekaragaman fitoplankton yang diperoleh selama pengamatan di Sungai Bengawan Solo berkisar antara 1,38 - 2,22, dengan indeks keseragaman berkisar antara 0,67-1,07 dan indeks dominasi yang menunjukkan kisaran 0,11-0,20. Uji korelasi regresi antara kelimpahan fitoplankton dengan konsentrasi nutrien (nitrat dan fosfat) di perairan Sungai Bengawan Solo memiliki nilai korelasi ganda positif sebesar 0,013. Konsentrasi fosfat berkisar antara 0,59$1,74 \mathrm{mg} / \mathrm{l}$. Hubungan antara kelimpahan fitoplankton dengan nitrat secara linier menunjukkan hubungan fluktuatif dengan nilai koefisien korelasi 0,277 dan koefisien determinasi sebesar 0,077 dimana 7,7\% kelimpahan fitoplankton dipengaruhi oleh nitrat. Hubungan antara kelimpahan fitoplankton dengan konsentrasi fosfat secara linier menunjukkan hubungan yang kuat dengan nilai koefisien korelasi 0,160 dan koefisien determinasi sebesar 0,025 dimana hanya 2,5\% kelimpahan fitoplankton dipengaruhi oleh fosfat. Status kesuburan perairan di Sungai Bengawan Solo Kota Surakarta tergolong dalam kategori mesotrofik yaitu perairan dengan tingkat kesuburan sedang.
\end{abstract}

Kata kunci: Sungai Bengawan Solo; Fitoplankton; Kesuburan Perairan

\section{ABSTRACT}

Household and industrial activities utilize the Bengawan Solo river to dispose of its waste. This can degrade the water quality in Bengawan Solo River. Changes in water quality will directly affect the organisms living in the river. The presence of phytoplankton in a waters can provide information about the state of the water. The purpose of this research is to know the structure of phytoplankton community, to know the concentration of nutrient (nitrate and phosphate) and to know the correlation of phytoplankton abundance with nutrient concentration. The results of this study indicate that the composition of phytoplankton species found during observation is dominated by the Bacillariophyceae class. Genus Rhizosolenia sp., Nitzschia sp. and Navicula sp. The abundance of phytoplankton at station I is 2544 ind / L. Station II of 1975 ind / L. Station III of 2735 ind / L. Station IV of 1785 ind / L and station V of 2418 ind / L. The phytoplankton diversity index obtained during observations on the Bengawan Solo River ranged from 1.38 to 2.22, with the uniformity index ranging from 0.67 to 1.07 and the dominance index showing a range of 0.11 to 0.20 . Regression correlation test between phytoplankton abundance with nutrient concentration (nitrate and phosphate) in Bengawan Solo River waters has positive double correlation value equal to 0,013. Phosphate concentrations ranged from 0.59 to $1.74 \mathrm{mg} / \mathrm{l}$. The relationship between abundance of phytoplankton and nitrate linearly showed a fluctuative relationship with the correlation coefficient value of 0.277 and the coefficient of determination of 0.077 where $7.7 \%$ of phytoplankton abundance was influenced by nitrate. The relationship between phytoplankton abundance with phosphate concentration linearly showed a strong correlation with correlation coefficient value of 0.160 and coefficient of determination equal to 0,025 where only 2.5\% phytoplankton abundance influenced by phosphate. The status of water fertility in the River Solo Solo City Surakarta classified in the mesotrophic category of waters with moderate fertility levels.

Keywords: Bengawan Solo River; Phytoplankton; Fertility Water

*) Penulis penanggungjawab

${ }^{\circledR}$ Copyright by Management of Aquatic Resources (MAQUARES) 


\section{PENDAhuluan}

Sungai Bengawan Solo merupakan sungai terbesar di Pulau Jawa, terletak di Provinsi Jawa Tengah dan Jawa Timur dengan luas wilayah sungai $\pm 12 \%$ dari seluruh wilayah Pulau Jawa pada posisi $110^{\circ} 18^{\prime}$ BT sampai $112^{\circ} 45^{\prime}$ BT dan $6^{\circ} 49^{\prime}$ LS sampai $8^{\circ} 08^{\prime}$ LS. Sungai Bengawan Solo secara administratif terletak pada 20 kabupaten/kota di Provinsi Jawa Tengah dan Jawa Timur. Dengan luas wilayah $20.125 \mathrm{~km}^{2}$. Wilayah Sungai Bengawan Solo terbagi menjadi 4 daerah aliran sungai (DAS) yaitu DAS Bengawan Solo, DAS Kali Grindulu dan Kali Lorog, DAS Pantura Gelangbang (Gresik-Lamongan-Tuban) dan DAS Kali Lamong (Keputusan Menteri No. 266 Tahun 2010).

Menurut Mudjib (2013), Sungai Bengawan Solo merupakan sungai yang penting bagi kehidupan masyarakat yang bermukim di sepanjang sungai tersebut. Aktivitas yang berlangsung di sepanjang sungai Bengawan Solo antara lain kegiatan perikanan, industri, pertanian dan pemanfaatan air untuk kebutuhan sehari-hari.

Kepadatan penduduk di sepanjang sungai sedkit banyak akan berpengaruh terhadap kondisi lingkungan perairan Sungai Bengawan Solo, sekitar 15,2 juta jiwa tinggal di SWS (Satuan Wilayah Sungai) Bengawan Solo. Di sekitar Kota Surakarta telah banyak industri (kurang lebih ada 50 pabrik) yang berdiri antara lain tekstil, alkhohol, penyamaan kulit, Mono Sodium Glutamate, industri tahu, dan lain-lain. Kegiatan rumah tangga dan industri memanfaatkan sungai Bengawan Solo untuk membuang limbahnya. Hal tersebut dapat menurunkan kualitas perairan di Sungai Bengawan Solo. Perubahan kualitas perairan akan berpengaruh langsung terhadap organisme yang hidup di sungai tersebut.

Keberadaan fitoplankton di suatu perairan dapat memberikan informasi mengenai keadaan perairan. Fitoplankton merupakan parameter biologi yang dapat dijadikan indikator untuk mengevaluasi kualitas dan tingkat kesuburan perairan. Hal inilah nantinya yang akan mengindikasikan tingkat kesuburan perairan di Sungai Bengawan Solo Kota Surakarta.

\section{MATERI DAN METODE PENELITIAN}

\section{a. Materi Penelitian}

Materi penelitian ini adalah sampel air yang diambil untuk menguji kadar nitrat, fosfat, kelimpahan fitoplankton dan beberapa variabel fisika kimia perairan yang diperoleh dari perairan Sungai Bengawan Solo Kota Surakarta.

Bahan yang digunkan dalam penelitian ini adalah Nitrat Ver5 Nitrate digunakan sebagai pereaksi nitrat; Phos Ver3 digunakan sebagai pereaksi fosfat; $\mathrm{HNO}_{3}$ digunakan untuk mencuci botol sampel sebagai wadah pengawetan dan aquades untuk membersihkan botol sampel sebelum digunakan.

Alat yang digunakan yaitu termometer untuk mengukur temperatur; bola arus untuk mengukur kecepatan arus; refraktrometer untuk mengukur nilai salinitas; $\mathrm{pH}$ meter untuk mengukur nilai $\mathrm{pH}$; dan cool box berisi es batu digunakan sebagai tempat penyimpanan sementara botol-botol sampel air; spektofotometer yang digunakan untuk analisa nilai nitrat dan fosfat; dan mikroskop untuk identifikasi fitoplankton.

\section{b. Metode Penelitian}

Metode yang digunakan dalam penelitian ini adalah metode survei, dengan tujuan untuk memperoleh faktafakta yang ada. Menurut Iqbal (2004) dalam Sumartini et al., (2013) metode survei dilakukan terhadap sekumpulan objek dengan asumsi bahwa objek yang diteliti telah mewakili populasi yang diamati.

\section{Penentuan lokasi sampling}

Lokasi pengambilan sampel dilakukan menggunakan metode purposive sampling, yakni pengambilan sampel secara sengaja dan dengan pertimbangan yang lainnya yang dianggap telah mewakili populasi dari lokasi penelitian. Menurut Ali (2013), metode purposive sampling yaitu penentuan titik pengambilan sampel air dengan melihat pertimbangan-pertimbangan yang dilakukan oleh peneliti antara lain didasari atas kemudahan akses, biaya maupun waktu dalam penelitian.. Pertimbangan yang diambil dalam menggunakan metode purposive sampling adalah lokasi pengambilan sampel air terdapat di lima lokasi sungai Bengawan Solo Kota Surakarta.

\section{Pengambilan sampel}

Pengukuran variabel fisika kimia perairan seperti: kecepatan arus, $\mathrm{pH}$, salinitas dan oksigen terlarut dilakukan secara in situ. Pengukuran dilakukan di setiap stasiun dengan titik pengamatan dibagi menjadi 3 setiap stasiun. Uji konsentrasi nitrat, fosfat dan pengamatan fitoplankton dilakukan di laboratorium PSDIL. Pengambilan air sampel untuk uji kadar nitrat dan fosfat diambil dengan menggunakan botol sampel dari tiaptiap titik sebanyak $250 \mathrm{ml}$.

Pengambilan sampel air untuk pengamatan fitoplankton dilakukan secara aktif menggunakan plankton net dengan ukuran mesh size $75 \mu \mathrm{m}$ dengan diameter $25 \mathrm{~cm}$. teknik pengambilan sampel fitoplankton dengan menarik plankton net secara horizontal menggunakan perahu dayung selama 1 menit dengan kecepatan konstan 2 knot yang dilihat dari GPS. Sampel air hasil penyaringan dimasukkan dalam botol sampel kemudian diberikan larutan lugol sebanyak 10 tetes. Sampel fitoplankton selanjurnya dilakukan pengamatan dengan menggunakan mikroskop di laboratorium. Identifikasi fitoplankton berdasarkan pada buku identifikasi Sachlan (1988).

\section{Analisa laboratorium}

Analisis dalam menghitung kelimpahan fitoplankton menggunakan metode sapuan Sedgwick Rafter Counting Cell dengan tiga kali ulangan dengan rumus (APHA,1976 dalam Sulardiono et al., 2015), yaitu : 
Keterangan :

$$
\mathrm{N}=\frac{\mathrm{T}}{\mathrm{L}} \mathrm{X} \frac{\mathrm{P}}{\mathrm{p}} \mathrm{X} \frac{\mathrm{V}}{\mathrm{v}} \mathrm{X} \frac{1}{\mathrm{w}}
$$

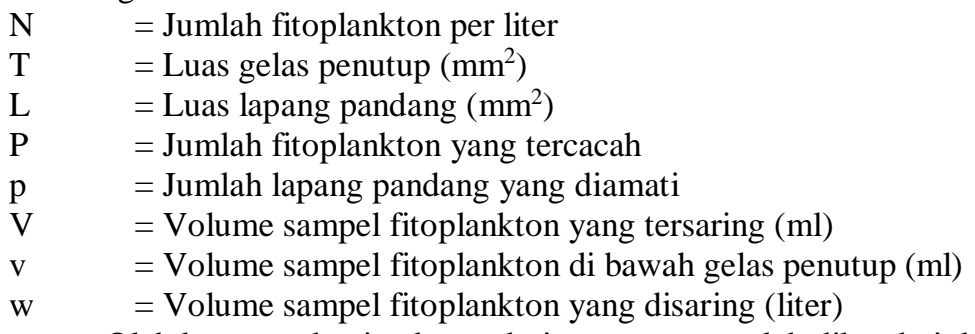

Oleh karena sebagian besar dari unsur-unsur telah diketahui dari sedgewick-rafter, seperti $\mathrm{T}=1000 \mathrm{~mm}^{2}$, $\mathrm{v}=1 \mathrm{ml}$, dan $\mathrm{L}=0,25 \mathrm{~mm}^{2}$ (1 lingkaran = luas lapang pandang pada mikroskop dengan nilai $\mathrm{r}=0,5 \mathrm{~mm}$ ), dengan demikian rumusnya menjadi : (Hartoko, 2010)

$$
\mathrm{N}=100(\mathrm{P} \times \mathrm{V}) / 0,25 \pi \mathrm{W} \text { (liter) }
$$

\section{Analisis data}

Hubungan antara kelimpahan fitoplankton dengan konsentrasi nitrat dan hubungan antara kelimpahan fitoplankton dengan fosfat menggunakan regresi linier. Keeratan hubungan antar variabel yang diamati diperhitungkan dengan koefisisen korelasi.

Hubungan antara nitrat dan fosfat terhadap kelimpahan fitoplankton dianalisis dengan regresi ganda. Menurut Sugiyono (2010), analisis regresi ganda dapat dilakukan jika peneliti bermaksud meramalkan keadaan (naik turunnya) variabel dependen, bila dua atau lebih variabel independen sebagai faktor prediktor dimanipulasi (dinaik turunkan nialinya). Adapun rumus yang digunakan sebagai berikut :

$$
\mathrm{Y}=\mathrm{a}+\mathrm{bX}
$$

Keterangan :

$$
\begin{aligned}
& \mathrm{Y} \quad=\text { Peubah terikat (kelimpahan fitoplankton) } \\
& \mathrm{X} \quad=\text { Parameter (nitrat atau fosfat) } \\
& \mathrm{b} \quad \text { = Konstanta } \\
& \text { Perangkat lunak yang digunakan dalam análisis adalah Microsoft Excel } 2007 .
\end{aligned}
$$

3. HASIL DAN PEMBAHASAN

a. Konsentrasi Nitrat, Fosfat dan Kelimpahan Fitoplankton

1.

Konsentrasi nitrat, fosfat dan kelimpahan fitoplankton pada setiap stasiun pengamatan disajikan pada Tabel

Tabel 1. Konsentrasi nitrat, fosfat dan kelimpahan fitoplankton pada setiap stasiun pengamatan

\begin{tabular}{ccccccc}
\hline Stasiun & $\begin{array}{c}\text { Nitrat } \\
\text { (mg/l) }\end{array}$ & $\begin{array}{c}\text { Tingkat } \\
\text { kesuburan }\end{array}$ & $\begin{array}{c}\text { Fosfat } \\
(\mathbf{m g} / \mathbf{l})\end{array}$ & $\begin{array}{c}\text { Tingkat } \\
\text { kesuburan }\end{array}$ & $\begin{array}{c}\text { Kelimpahan } \\
\text { fitoplankton (ind/I) }\end{array}$ & $\begin{array}{c}\text { Tingkat } \\
\text { kesuburan }\end{array}$ \\
\hline I & 2,911 & Mesotrofik & 1,193 & Oligotrofik & 880 & Oligotrofik \\
II & 3,463 & Mesotrofik & 1,118 & Oligotrofik & 701 & Oligotrofik \\
III & 1,219 & Mesotrofik & 1,738 & Oligotrofik & 763 & Oligotrofik \\
IV & 3,548 & Mesotrofik & 0,59 & Oligotrofik & 680 & Oligotrofik \\
V & 1,197 & Mesotrofik & 0,613 & Oligotrofik & 848 & Oligotrofik \\
\hline
\end{tabular}

Konsentrasi nitrat $\left(\mathrm{NO}_{3}\right)$ di perairan Sungai Bengawan Solo pada 5 stasiun berkisar antara 1,197 - 3,548 mg/l. termasuk dalam kategori mesotrofik. Menurut Effendi (2003), kisaran nitrat bagi kesuburan perairan yaitu $0-<1 \mathrm{mg} / \mathrm{l}$ termsuk dalam kategori oligotrofik, $1-<5 \mathrm{mg} / \mathrm{l}$ termasuk dalam kategori mesotrofik dan $5-50$ termasuk dalam kategori eutrofik.

Konsentrasi nitrat tertinggi terdapat pada stasiun IV yaitu 3,548 mg/l. dan konsentrasi nitrat terendah terdapat pada stasiun V yaitu 1,197 mg/l. Kondisi kualitas air Sungai Bengawan Solo Kota Surakarta masih dalam batas baku mutu air sesuai peruntukannya, meskipun di sepanjang sungai masih banyak terdapat aktivitas rumah tangga, industri dan pertanian. Hal ini mungkin disebabkan adanya proses pengenceran sepanjang aliran Sungai Bengawan Solo sehingga konsentrasi bahan pencemar menurun. Menurut Tatangindatu (2013), nitrat adalah bentuk utama nitrogen di perairan alami dan merupakan sumber nutrisi utama bagi pertumbuhan fitoplankton dan tumbuhan air lainnya. Kadar nitrat yang lebih dari $5 \mathrm{mg} / \mathrm{l}$ menggambarkan telah terjadinya pencemaran.

Tingginya konsentrasi nitrat pada stasiun III di perairan Sungai Bengawan Solo Kota Surakarta disebabkan tingginya masukan nitrat baru dari lingkungan sekitar. Hal ini sangat memungkin terjadi mengingat di sepanjang aliran Sungai Bengawan Solo Kota Surakarta merupakan kawasan padat permukiman penduduk dan banyak ditemukan industri-industri mulai dari skala kecil hingga skala besar. Menurut Boyd (1990) dalam Lestari (2013) 
adanya aktivitas masyarakat urban dapat member kontribusi bahan organik yang banyak mengandung senyawa nitrat. Disamping itu adanya pengaruh turbulensi yang dapat mengangkat senyawa nitrat dari dasar kolom air terutama pada perairan yang dangkal. Dilihat dari histogram konsentrasi nitrat secara keseluruhan masih baik untuk pertumbuhan organisme perairan khususnya fitoplankton. Hal ini diperkuat oleh pernyataan Simanjuntak (2012) algae khususnya fitoplankton akan dapat tumbuh normal pada kisaran nitrat $0,9-3,5 \mathrm{mg} / \mathrm{l}$.

Fosfat merupakan salah satu zat hara yang dibutuhkan dan mempunyai pengaruh terhadap pertumbuhan dan perkembangan hidup organisme perairan. Tinggi rendahnya kadar fosfat dan nitrat di suatu perairan adalah salah satu indikator untuk menentukan kesuburan perairan (Patty, 2014). Konsentrasi Fosfat $\left(\mathrm{PO}_{4}\right)$ di perairan Sungai Bengawan Solo Kota Surakarta berkisar antara 0,59 - 1,74 mg/l. Konsentrasi fosfat tertinggi terdapat pada stasiun III yaitu 1,74 mg/l. dan konsentrasi fosfat terendah terdapat pada stasiun IV yaitu 0,59 mg/l.

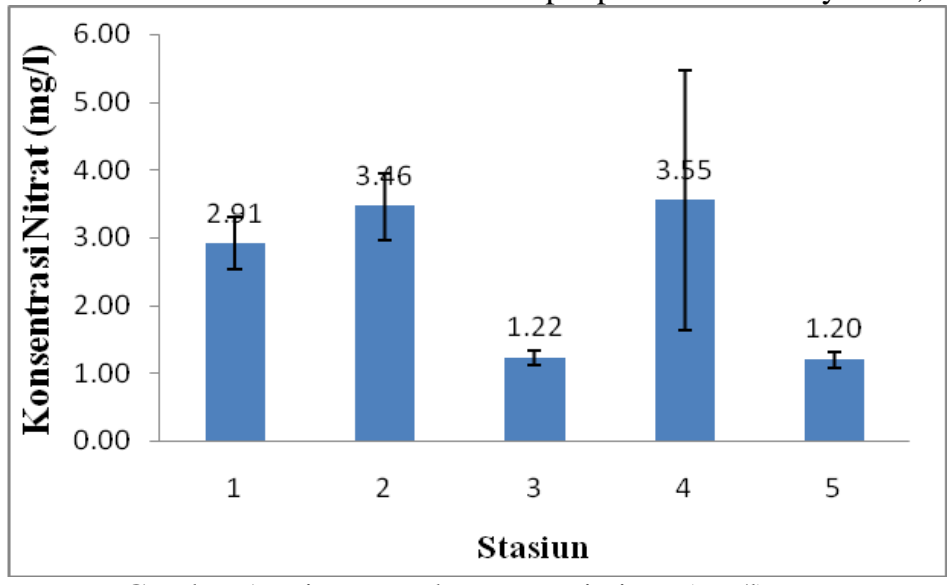

Gambar 1. Histogram konsentrasi nitrat (mg/l)

Konsentrasi fosfat secara keseluruhan dari kelima stasiun pengamatan di perairan Sungai Bengawan Solo Kota Surakarta tergolong dalam kategori kesuburan perairan oligotroik. Hal ini sesuai dengan penelitian yang dilakukan Ayuningsih et al., (2014) di perairan Teluk Sekumbu Jepara dengan kisaran nilai fosfat 0,38 - 1,74 termasuk dalam kategori oligotrofik yang mempunyai kesuburan perairan rendah.

Tingginya konsentrasi fosfat di stasiun III sebesar $1,738 \mathrm{mg} / \mathrm{l}$ diduga karena banyaknya aktivitas rumah tangga yang membuang limbahnya ke periran sungai Bengawan Solo. Menurut Effendi (2003), sumber utama fosfat adalah penumpukan dari kegiatan pertanian dan pertambakan, limbah industri atau bahkan limbah rumah tangga. Konsentrasi fosfat terendah diperoleh pada stasiun IV sebesar $0,59 \mathrm{mg} / \mathrm{l}$ hal ini diduga adanya proses metabolisme oleh mikroorganisme. Menurut Bengen (2004) dalam Amelia (2014), mengatakan bahwa rendahnya konsentrasi fosfat disebabkan karena pemanfaatan senyawa fosfor oleh mikroorganisme untuk metabolisme atau diserap oleh tanaman.

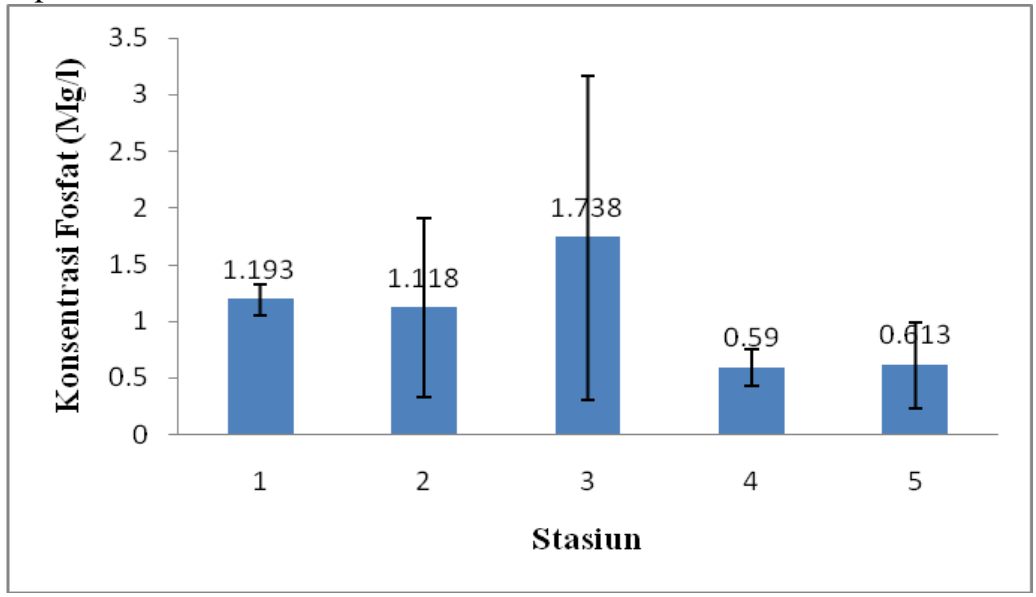

Gambar 2. Histogram konsentrasi fosfat (mg/l)

Kelimpahan fitoplankton diartikan sebagai jumlah individu fitoplankton persatuan volume air per liter (ind/l). Lingkungan yang kurang baik dapat menyebabkan jumlah individu atau kelimpahan fitoplankton berkurang. Keadaan ini dapat mempengaruhi tingkat kesuburan perairan. Oleh karena itu kesuburan perairan ditentukan melalui kelimpahan fitoplankton. Kelimpahan fitoplankton yang didapatkan memiliki kelimpahan tertinggi pada stasiun I sebesar 880 individu/liter dengan rata-rata kelimpahan sebesar 110 individu/liter. Tingginya kelimpahan fitoplankton pada stasiun I dibandingkan dengan stasiun lainnya karena didukung oleh kualitas perairan yang cukup baik dengan nilai kandungan nitrat sebesar $2,911 \mathrm{mg} / \mathrm{l}$. Hal ini sesuai dengan penelitian Meiriyani et al., (2012) di perairan Sungai Way Belau Bandar Lampung fitoplankton yang subur 
umumnya terdapat di perairan sekitar muara sungai atau perairan lepas pantai dimana terjadi air naik (up welling). Di kedua lokasi itu terjadi proses penyuburan karena masuknya zat hara ke dalam lingkungan perairan tersebut. Selain itu pada stasiun I terdapat beberapa warga yang menggembalakan hewan ternak (kambing) di pinggir badan sungai, dimana kotoran hewan ternak masuk ke dalam perairan dan menyebabkan tingginya kandungan nutrient di perairan. Hal ini diperkuat oleh Sumartini (2013), kotoran hewan yang terbawa hujan menuju ke badan perairan tentunya memberikan pengaruh pada pertumbuhan fitoplankton karena kotoran tersebut mengandung nutrient.

Kelimpahan fitoplankton terendah pada stasiun IV yaitu 680 individu/liter dengan rata-rata kelimpahan 85 individu/liter. Hal ini disebabkan pada stasiun pengamatan IV Sungai Bengawan Solo Kota Surakarta memiliki kecepatan arus yang tinggi yaitu sebesar $0,153 \mathrm{~m} / \mathrm{s}$ dan juga kandungan oksigen terlarut yang rendah sebesar 5,8 mg/l menyebabkan fitoplankton tidak dapat berkembang baik. Hal ini diperkuat oleh pendapat Whitton (1975) dalam Sumartini (2013), kecepatan arus adalah faktor penting di perairan mengalir. Kecepatan arus yang besar (>5 m/detik) mengurangi jenis flora yang dapat tinggal sehingga hanya jenis-jenis yang melekat saja yang tahan terhadap arus dan tidak mengalami keruskan fisik.

Berdasarkan hasil kelimpahan fitoplankton yang didapat dari kelima stasiun pengamatan di perairan Sungai Bengawan Solo Kota Surakarta menunjukkan bahwa perairan tersebut tergolong kategori perairan oligotrofik. Menurut Landner (1978) dalam Suryanto (2009), perairan oligotrofik merupakan perairan yang tingkat kesuburan rendah dengan kelimpahan fitoplankton berkisar antara 0 - 2000 individu/liter. Perairan mesotrofik merupakan perairan yang tingkat kesuburan sedang dengan kelimpahan fitoplankton berkisar $2000-15.000$ individu/liter. Perairan eutrofik merupakan perairan yang tingkat kesuburan tinggi dengan kelimpahan fitoplankton berkisar antara $>15.000$ individu/liter.

\section{b. Variabel fisika kimia pendukung}

Hasil pengukuran variabel fisika kimia pendukung di setiap stasiun dapat dilihat pada tabel 2. Tabel 2. Hasil Pengukuran Variabel Fisika Kimia Pendukung Selama Penelitian

\begin{tabular}{lccccccc}
\hline \multicolumn{1}{c}{ Variabel } & \multicolumn{3}{c}{ Stasiun } & & $\overline{\mathbf{X}}$ & \multirow{2}{*}{$\mathbf{S}$} \\
\cline { 2 - 6 } & $\mathbf{1}$ & $\mathbf{2}$ & $\mathbf{3}$ & $\mathbf{4}$ & $\mathbf{5}$ & & \\
\hline Temperatur air $\left({ }^{0} \mathrm{C}\right)$ & 26 & 28 & 26 & 26 & 27 & 26,4 & 0.49 \\
Kecepatan arus $(\mathrm{m} / \mathrm{s})$ & 0,132 & 0,14 & 0,142 & 0,153 & 0,135 & 0,14 & 0.184 \\
Oksigen terlarut $(\mathrm{mg} / \mathrm{l})$ & 6,8 & 8,6 & 6,5 & 5,8 & 6,7 & 6,9 & 0.93 \\
pH & 5 & 5 & 6,7 & 7 & 6,7 & 6,08 & 0.89 \\
Salinitas & 0 & 0 & 0 & 0 & 0 & 0 & 0 \\
\hline
\end{tabular}

Semua variabel fisika kimia pendukung pada perairan Sungai Bengawan Solo Kota Surakarta telah sesuai dengan kisaran yang telah ditetapkan Peraturan Pemerintah No. 82 Tahun 2001 tentang baku mutu pengelolaan kualitas air dan pengendalian pencemaran air. Hasil yang diperoleh dari pengukuran, rata-rata temperatur di kelima stasiun berkisar antara $26^{\circ} \mathrm{C}-28^{\circ} \mathrm{C}$. Temperatur perairan di kelima stasiun sudah termasuk baik untuk pertumbuhan fitoplankton. Hal ini sesuai dengan pernyataan Ray dan Rao, 1963 dalam Sulardiono et al., (2015), bahwa secara umum temperatur optimal bagi perkembangan plankton adalah $20^{\circ} \mathrm{C}-30^{\circ} \mathrm{C}$.

Rata-rata kecepatan arus yang diperoleh dari kelima stasiun pengamatan berkisar antara 0,132 - 0,153 m/s. Kecepatan arus di kelima stasiun pengamatan di sungai Bengawan Solo Kota Surakarta tergolong lambat. Diduga karena adanya sampah-sampah yang dibuang ke badan perairan sehingga dapat memperlambat kecepatan arus. Hal ini sesuai dengan penelitian yang dilakukan oleh Susanti Lawati Barus (2013), di perairan Sungai Deli Sumatra Utara menyatakan bahwa kisaran kecepatan arus yang diperoleh berkisar 0,68 - 0,89 tergolong cepat. Arus dibagi menjadi 5 yaitu arus yang sangat cepat $(>1 \mathrm{~m} / \mathrm{s})$, cepat $(0,5-1 \mathrm{~m} / \mathrm{s})$, sedang $(0,25$ $-0,5 \mathrm{~m} / \mathrm{s})$, lambat $(0,1-0,25 \mathrm{~m} / \mathrm{s})$ dan sangat lambat $(<0,1 \mathrm{~m} / \mathrm{s})$.

Rata-rata $\mathrm{pH}$ di perairan Sungai Bengawan Solo Kota Surakarta berkisar antara $5-7$. Nilai $\mathrm{pH}$ terendah terdapat pada stasiun I dan II yaitu 5. Hal ini dikarenakan pada saat pengambilan sampel hari sebelumnya turun hujan deras sehingga sungai mendapatkan pasokan air laut berlebih dan juga adanya aktivitas warga sekitar yang menggembala ternak di sekitar sungai. Konsentrasi pH kurang dari 6 akan menghentikan proses nitrifikasi yang menyebabkan mikroorganisme perairan mati. Menurut Effendi (2003), nilai pH akan mempengaruhi prosesprose biokimia perairan, misalnya proses nitrifikasi akan berakhir jika $\mathrm{pH}$ kurang dari 6 (asam). Nilai pH untuk stasiun III, IV dan V dirasa sudah cukup optimum karena berada pada kisaran 7. Biota lainnya seperti ikan pada kisaran $\mathrm{pH} 7$ - 8 dapat berkembangbiak secara baik. Perairan tersebut juga dikatakan subur karena $\mathrm{pH}$ tidak terlalu basa dan tidak terlalu asam. Menurut Santoso (2007) dalam Arizuma (2014) organisme akuatik dapat hidup dalam suatu perairan yang mempunyai nilai $\mathrm{pH}$ yang netral dengan kisaran toleransi antara asam lemah sampai basa lemah. $\mathrm{pH}$ yang ideal bagi kehidupan organisme akuatik umumnya berkisar antara $7-8,5$. Kondisi perairan yang bersifat sangat asam maupun sangat basa membahayakan kelangsungan hidup organisme karena menyebabkan terjadinya gangguan metabolisme dan respirasi.

Rata-rata konsentrasi oksigen terlarut yang diperoleh dari kelima stasiun berkisar anatar 5,8 - 8,6 mg/l. Konsentrasi oksigen terlarut dari setiap stasiun berbeda-beda, hal ini disebabkan oleh banyak sedikitnya organisme perairan yang mengkonsumsi oksigen terlarut dan juga disebabkan oleh temperatur. Temperatur dengan oksigen terlarut berbanding lurus apabila nilai oksigen terlarut tinggi maka suhu juga tinggi. Pengamatan

\footnotetext{
${ }^{\circledR}$ Copyright by Management of Aquatic Resources (MAQUARES)
} 
pada stasiun II ditemukan nilai oksigen terlarut tinggi yaitu $8,6 \mathrm{mg} / \mathrm{l}$ dan temperatur air juga tinggi yaitu $28^{\circ} \mathrm{C}$. Menurut Situmorang (2007) dalam Sinambela (2015), kelarutan oksigen di dalam air terutama sangat dipengaruhi oleh temperatur dan mineral terlarut dalam air. Kelarutan maksimum oksigen dalam air terdapat pada temperatur $0^{\circ} \mathrm{C}$, yaitu sebesar $14,16 \mathrm{mg} / \mathrm{l}$. konsentrasi ini akan menurun seiring peningkatan ataupun penurunan temperatur. Sumber utama oksigen terlarut dalam perairan adalah dari proses fotosintesis tumbuhan dan penyerapan/pengikatan secara langsung oksigen dari udara bebas melalui kontak antara permukaan air dengan udara.

Konsentrasi oksigen terlarut terendah terdapat pada stasiun IV yaitu $5,8 \mathrm{mg} / \mathrm{l}$. dengan temperature air $26^{\circ} \mathrm{C}$, namun konsentrasi tersebut masih berada di atas batas minimum yang telah ditetapkan dan aman untuk pertumbuhan fitoplankton dan organisme perairan lainnya. Umumnya konsentrasi oksigen terlarut sebesar 5,0 ppm dengan temperature air berkisar $20-30^{\circ} \mathrm{C}$ relatif masih baik untuk kehidupan ikan-ikan, bahkan apabila dalam perairan tidak terdapat senyawa-senyawa yang bersifat toksik konsentrasi oksigen sebesar 2,0 ppm sudah cukup untuk mendukung kehidupan organisme perairan (Marabessy et al., 2005 dalam Arizuma, 2014).

\section{c. Hubungan antar variabel nitrat, fosfat dan kelimpahan fitoplankton}

Berdasarkan pengamatan kelimpahan fitoplankton dengan konsentrasi nitrat memiliki keeratan yang sangat kuat. Hal tersebut dapat dilihat pada hasil analisis hubungan kelimpahan fitoplankton dengan konsentrasi nitrat yang tersaji pada gambar 1.

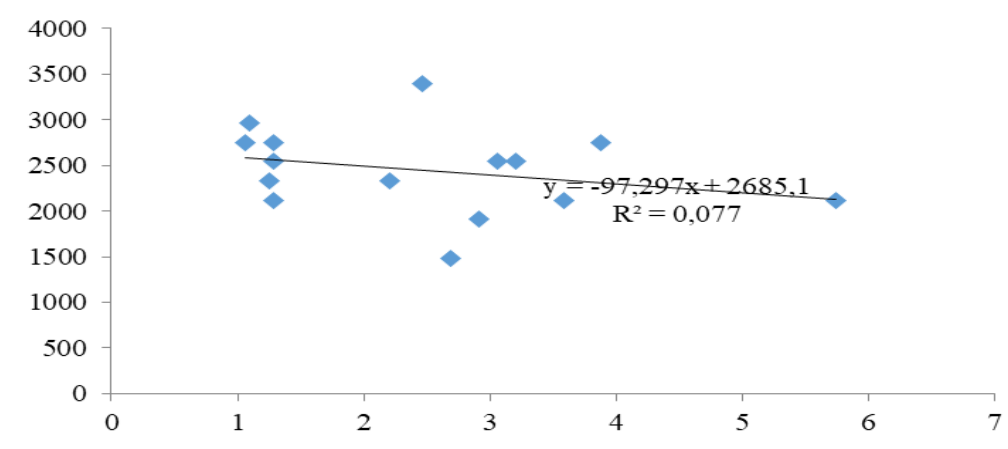

Gambar 3. Grafik Hubungan Kelimpahan Fitoplankton dengan Konsentrasi Nitrat

Hubungan antara kelimpahan fitoplankton dengan konsentrasi nitrat fluktuatif. Diperoleh persamaan $\mathrm{Y}=\mathrm{-}$ $97,29 x+2685$. Nilai koefisien korelasi (r) sebesar 0,277. Nilai ini memberikan informasi bahwa hubungan kelimpahan fitoplankton dengan konsentrasi nitrat berhubungan fluktuatif yaitu kenaikan nilai konsentrasi nitrat tidak mempengaruhi kelimpahan fitoplankton. Perubahan konsentrasi nitrat setiap saat berubah-ubah dan tidak selalu menunjukkan kenaikan atau penurunan. Sedangkan nilai koefisien determinasi sebesar $\left(\mathrm{R}^{2}\right)$ sebesar 0,077 . Hal ini memberikan informasi bahwa sebesar 7,7\% kelimpahan fitoplankton dipengaruhi oleh konsentrasi nitrat sedangkan 92,3\% lainnya dipengaruhi oleh faktor parameter fisika kimia perairan lainnya.

Hubungan antara kelimpahan fitoplankton dengan konsentrasi fosfat fluktuatif. Hal tersebut dapat dilihat pada gambar 2 .

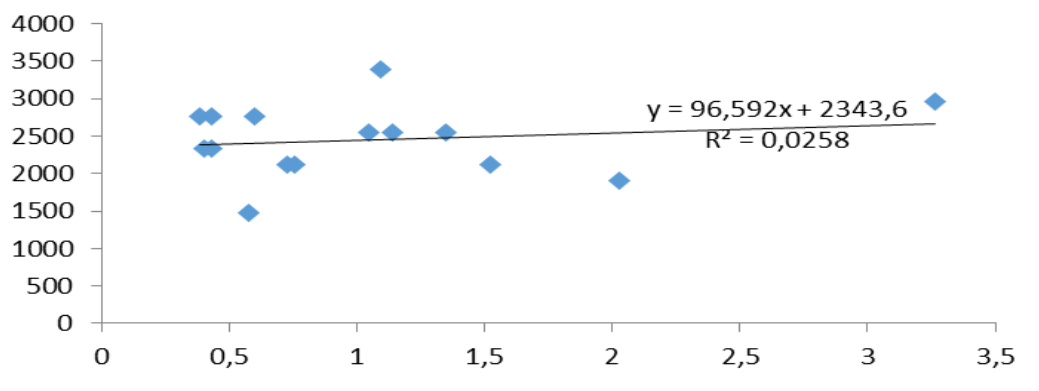

Gambar 4. Grafik Hubungan Kelimpahan Fitoplankton dengan Konsentrasi Fosfat

Hubungan antara kelimpahan fitoplankton dengan konsentrasi fosfat menunjukkan fluktuatif (tidak signifikan). Diperoleh persamaan $\mathrm{Y}=96,59 \mathrm{x}+23,43$. Nilai koefisien korelasi $(\mathrm{r})$ sebesar 0,160 . Nilai ini memberikan informasi bahwa hubungan kelimpahan fitoplankton dengan konsentrasi fosfat berhubungan fluktuatif (tidak signifikan) dimana kenaikan konsentrasi fosfat tidak mempengaruhi kelimpahan fitoplankton. Perubahan konsentrasi nitrat setiap saat berubah-ubah dan tidak selalu menunjukkan kenaikan atau penurunan.

Sedangkan nilai koefisien determinasi $\left(\mathrm{R}^{2}\right)$ sebesar 0,025 . Hal ini memberikan informasi bahwa sebesar 2,5\% kelimpahan fitoplankton dipengaruhi oleh konsentrasi fosfat sedangkan 97,5\% lainnya dipengaruhi oleh faktor parameter fisika kimia perairan lainnya. Menurut Tungka et al.,(2016) faktor fisika kimia lainnya yang mempengaruhi kelimpahan fitoplankton selain nitrat dan fosfat adalah temperatur, salinitas, oksigen terlarut dan 
lainnya. Kelimpahan fitoplankton pada suatu perairan selalu berkaitan erat dengan kondisi di sekitar lingkungan perairan tersebut.

Analisis pola hubungan kelimpahan fitoplankton dengan konsentrasi fosfat pada perairan Sungai Bengawan Solo Kota Surakarta menggunakan regresi linier, menunjukkan hubungan positif. Hal tersebut menunjukkan bahwa peningkatan konsentrasi fosfat akan meningkatkan kelimpahan fitoplankton. Fosfat di perairan Sungai Bengawan Solo berasal dari limbah kegiatan masyarakat sekitar seperti kegiatan rumah tangga, pertanian dan industri yang bermuara ke Sungai Bengawan Solo. Hal ini sesuai dengan pernyataan Santoso (2006) dalam Barokah et al., (2016) tingginya senyawa fosfat pada perairan disebabkan oleh kegiatan budidaya perikanan di perairan tersebut serta limpasan air sungai dari kegiatan pertambakan dan pertanian. Menurut Hasani et al., (2012) konsentrasi fosfat pada perairan yang lebih dari $0,1 \mathrm{mg} / \mathrm{l}$ menunjukkan bahwa perairan tersebut mengalami eutrofikasi.

Hubungan secara keseluruhan antara kadar nitrat, kadar fosfat, dengan kelimpahan fitoplankton dapat dilihat pada hasil regresi ganda yang menunjukkan nilai kelimpahan fitoplankton $=110,61-4,77 \mathrm{NO}_{3}-1,93$ dengan koefisisen korelasi $(r)=0,49$ dan koefisien determinasi $\left(R^{2}\right)=0,244$ yang menunjukkan bahwa kelimpahan fitoplankton lebih banyak dipengaruhi oleh nitrat daripada fosfat. Hal ini sesuai dengan penelitian Tungka (2016) di Sungai Banjir Kanal Barat Semarang yang menyatakan bahwa nitrat seringkali menjadi faktor pembatas utama dalam produktivitas primer fitoplankton di muara.

\section{KESIMPULAN}

Berdasarkan hasil penelitian yang telah dilakukan di perairan Sungai Bengawan Solo Kota Surakarta, dapat disimpulkan bahwa konsentrasi fosfat di perairan Sungai Bengawan Solo Kota Surakarta tergolong dalam kategori tingkat kesuburan mesotrofik yaitu berkisar antara $0,59-1,74 \mathrm{mg} / \mathrm{l}$. Konsentrasi nitrat di perairan Sungai Bengawan Solo Kota Surakarta berikisar antara 1,197 - 3,548 tergolong kategori mesotrofik. Hubungan antara kelimpahan fitoplankton dengan nitrat menunjukkan hubungan fluktuatif dengan nilai koefisien korelasi 0,277 dan koefisien determinasi sebesar 0,077 dimana 7,7\% kelimpahan fitoplankton dipengaruhi oleh nitrat. Hubungan antara kelimpahan fitoplankton dengan fosfat menunjukkan hubungan fluktuatif dengan nilai koefisien korelasi 0,160 dan koefisien determinasi sebesar 0,025 dimana hanya 2,5\% kelimpahan fitoplankton dipengaruhi oleh fosfat. Status kesuburan perairan di Sungai Bengawan Solo Kota Surakarta tergolong dalam kategori mesotrofik yaitu perairan dengan tingkat kesuburan sedang.

\section{UCAPAN TERIMA KASIH}

Penulis menyampaikan terima kasih kepada masyarakat sekitar Sungai Bengawan Solo Kota Surakarta atas pemberian izin melakukan penelitian dan membantu pelaksanaan sampling lapangan, serta Dr. Ir Pujiono Wahyu Purnomo, MS dan Churun 'Ain, S.Pi, M.Si yang telah memberikan saran dan masukan dalam penulisan skripsi ini.

\section{DAFTAR PUSTAKA}

Ali, A., Soemarno dan M. Purnomo. 2013. Kajian Kualitas Air dan Status Mutu Air Sungai Metro di Kecamatan Sukun Kota Malang. Jurnal Bumi Lestari, 13(2): 265-274.

Amelia, Y., M. R. Muskananfola dan P. W. Purnomo. 2014. Sebaran Struktur Sedimen, Bahan Organik, Nitrat dan Fosfat di Perairan Dasar Muara Morodemak. Journal .Of Maquares. Vol 3 no 4 Hal : 208-215.

Arizuna, M., D. Suprapto dan M. R. Muskananfola. 2014. Kandungan Nitrat dan Fosfat dalam Air Pori Sedimen di Sungai dan Muara Sungai Wedung Demak. Journal Of Maquares. Vol 3 No 1 Hal : 7-16

Ayuningsih, M. S., I. B. Hendrarto dan P. W. Purnomo. 2014. Distribusi Kelimpahan Fitoplankton dan Klorofila di Teluk Sekumbu Kabupaten Jepara : Hubungannya Dengan Kandungan Nitrat dan Fosfat di Perairan. Journal Of Maquares, 3(2): 138-147.

Barokah, G. R., A. K. Putri dan Gunawan. 2016. Kelimpahan Fitoplankton Penyebab HAB (Harmful Algal Bloom) di Perairan Teluk Lampung pada Musim Barat dan Timur. Pusat Penelitian dan Pengembangan Daya Saing Produk dan Bioteknologi Kelautan dan Perikanan. Jakarta.

Barus, Susanti L., Yunasfi dan Ani Suryanti. 2013. Keanekaragaman dan Kelimpahan Perifiton di Perairan Sungai Deli Sumatera Utara. Program Studi Manajemen Sumberdaya Perairan, Universitas Sumatera Utara, Medan.

Effendi, H. 2003. Telaah Kualitas Air Bagi Pengelolaan Sumber Daya dan Lingkungan Perairan. Penerbit Kanisius, Yogyakarta, $258 \mathrm{hlm}$.

Hasani, Q., Enan Mulyana Adiwilaga dan Niken Tunjung Murti P. 2012. The Relationship between the Harmful Algal Blooms (HABs) Phenomenon with Nutrients at Shrimp Farms and Fish Cage Culture Sites in Pesawaran District Lampung Bay. Makara Journal of Science. Vol 16 No 3 Hal 183-191.

Kurniawan, D., 2008. Regresi Linier (Linear Regression). Foundation For Statistical Computing. Vienna, Austria. 
Lestari, Febrianti. 2013. Sebaran Nitrogen Anorganik Terlarut di Perairan Pesisir Kota Tanjungpinang, Kepulauan Riau. Jurnal Dinamika Maritim. Vol 4 No 2 Hal : 88-96

Meiriyani, F., Tengku Zia Ulqodry, Wike Ayu Eka Putri. 2011. Komposisi dan Sebaran Fitoplankton di Perairan Muara Sungai Way Bealu, Bandar Lampung. Jurnal Maspari, 3: 69-77.

MENPU (Menteri Pekerjaan Umum). 2010. Keputusan Menteri Pekerjaan Umum Nomor 266/KPTS/M/2010. Pola Pengelolaan Sumberdaya Air Wilayah Sungai Bengawan Solo. Lampiran.

Mudjib, Chandra Murprabowo dan Umboro Lasminto. 2013. Studi Angkutan Sedimen Sudetan PelangwotSedayu Lawas Sungai Bengawan Solo. Jurnal Teknik Pomits, 2(3).

Patty, Simon I. 2014. Karakteristik Fosfat, Nitart dan Oksigen Terlarut di Perairan Pulau Gangga dan Pulau Siladen, Sulawesi Utara. Jurnal Ilmiah Platax, 2(2).

Peraturan Pemerintah Nomor 82 tahun 2001 tentang Pengelolaan Kualitas Air dan Pengendalian Pencemaran Air. Lampiran.

Razak, A. 1991. Statistika Bidang Pendidikan. Fakultas Keguruan dan Ilmu Pendidikan. Universitas Riau, Pekanbaru.

Simanjuntak, Marojahan. 2012. Kualitas Air Laut Ditinjau Dari Aspek Zat Hara, Oksigen Terlarut dan pH di Perairan Banggai, Sulawesi Tengah. Jurnal Ilmu dan Teknologi Kelautan Tropis. Vol 4 No 2 Hal 290303.

Sinambela, Masdiana dan Mariaty Sipayung. 2015. Makrozoobentos Dengan Parameter Fisika dan Kimia di Perairan Sungai Babura Kabupaten Deli Serdang. Jurnal Biosains, 1(2).

Sugiyono. 2010. Statistika Untuk Penelitian. Alfabeta. Yogyakarta. $390 \mathrm{hlm}$.

Sulardiono, B., Sahala Hutabarat dan Ali Djunaedi. 2015 Buku Ajar Planktonologi. LPPM Universitas Diponegoro, Semarang. $121 \mathrm{hlm}$.

Sumartini, S., Suryanti dan Siti Rudiyanti. 2013. Kualitas Perairan Sungai Seketak Semarang Berdasarkan Komposisi dan Kelimpahan Fitoplankton. Journal Of Maquares, 2(2): 38-45.

Suryanto, Asus Maizar dan Herwati Umi S. 2009. Pendugaan Status dengan Pendekatan Kelimpahan Fitoplankton dan Zooplankton di Waduk Sengguruh, Karangkates, Lahor, Wlingi Raya dan Wonorejo Jawa Timur. Jurnal Ilmiah Perikanan dan Kelautan. 1(1).

Tatangindatu, F., Ockstan Kalesarn dan Robert Rompas. 2013. Studi Parameter Fisika Kimia Air pada Areal Budidaya ikan di Danau Tondano, Desa Paleloan, Kabupaten Minahasa. Jurnal Budidaya Perairan, 1(2): 8-19.

Tungka, Anggita W., Haeruddin dan Churuun Ain. 2016. Konsentrasi Nitrat dan Ortofosfat di Muara Sungai Banjir Kanal Barat dan Kaitannya dengan Kelimpahan Fitoplankton Harmful Alga Blooms (HABs). Jurnal Saintek Perikanan, 12(1): 40-46. 